bend of fourth vein is far removed from hind margin of wing, being almost as close to the front as to the hind margin.

Chætocraniopsis chilensis, new species.

Length of body, $10 \mathrm{~mm}$; of wing, $6.5 \mathrm{~mm}$. One male, Chile (E. C. Reed).

Dark brown or blackish, parafrontals and parafacials silvery white pollinose, cheek grooves brownish rufous, palpi yellow, second antennal joint rufous, third antennal joint and fascial plate blackish with a faint silvery bloom, arista soft black. Mesoscutum thinly silvery, leaving four equal vittæ; scutellum pale fulvous, thinly silvery; abdomen rather thickly silvery pollinose on second and third segments except narrow hind margin. Legs wholly blackish, hind tibiæ with unequal bristles, claws slightly longer than last tarsal joint. Wings nearly clear, showing no yellowish at base; tegulæ white.

First and second abdominal segments of male with a median marginal pair of macrochætæ, the first segment with one lateral marginal, the second with two or three lateral marginal, the third and fourth with closely set marginal row. Apical pair of scutellar bristles rather short, erect; three long lateral pairs, and one shorter discal pair. Front of male about as wide as both eyes, face slightly wider; facial depression deeply excavated, about as wide as parafacials; cheeks of male a little less than one-half eye-height.

Holotype, No. 19419, U. S. Nat. Mus.

\title{
NEW PERUVIAN HYSTRICIINE FLIES
}

BY CHARLES H. T. TOWNSEND

Neogymnomma, new genus.

Differs from Gymnomma as follows: Cheeks of female about two-thirds eye-height. Parafacials with bristly hairs, one facio-orbital bristle present. No ocellar bristles. Third antennal joint no longer than the elongate second, very wide and truncate at end. Second aristal joint very elongate. No palpi. Front tarsi of female widened. Abdomen thickly beset with slightly curved subspinelike macrochætæ, scutellum with same. Cubitus with wrinkle only. 
Neogymnomma rufa, new species.

Length of body, $9.5 \mathrm{~mm}$; of wing, $9.5 \mathrm{~mm}$. One female; Huariaca, Peru, high montanya of the Rio Huallaga Canyon, about 10,750 feet, December 21, 1913 ('Townsend).

Rufous to lighter. Face and cheeks light in ground color, pale golden pollinose; parafrontals blackish, old-gold pollinose. Frontalia and first two antennal joints pale rufous, also a tinge of same on base of third, rest of third joint blackish. Occiput golden, with pale gold beard. Bristly hairs of parafacials, parafrontals and cheeks black, those of cheeks shorter. Mesoscutum old-gold pollinose; four narrow olive vittæ, the inner ones stopping a little behind suture, the outer ones interrupted and stopping short of scutellum. Mesopleuræ oldgold, rest of pleuræ paler golden. Scutellum light rufous, with pale golden pollen. Abdomen wholly rufous above and below, the tergum deeply colored and the venter paler, showing a very faint grayish bloom changing to pale golden along incisures, especially on base of anal segment. Legs pale rufous, about same as venter and hardly lighter than base of antennæ. Wings uniformly smoky, with a barely perceptible flavous element. Tegulæ smoky-blackish, with yellowish. margins.

Holotype, No. 19420, U. S. Nat. Mus. TD4215.

\section{Uruhuasiopsis, new genus.}

Genotype, Uruhuasiopsis analis Townsend, new species.

Differs from Uruhuasia (Subgenus A) as follows: Male front at vertex decidedly less than eye width; a long hair-like proclinate pair of ocellar bristles; proboscis about one and threefourths times head height; palpi slender, nipple-like, tipped by two hairs. Frontal bristles anteriorly in double row; five pairs back of root of antennæ not counting the strongly divaricate upper orbital pair in row with them. Three sternopleural, four postsutural, three postacrostichal, two preacrostichal, and three dorsocentral bristles. Abdomen no wider than thorax, narrow-oval; second segment with a median discal and a median marginal pair; third segment with median discal and marginal row; fourth with discal row, and submarginal and marginal 
bristles. Apical cell not so elongate, ending one and one-half times as far from wing-tip as length of fourth vein between hind crossvein and bend, said length being hardly one-third of length between hind and small crossveins. Lateral discals of second and third segments weak, especially those of second. Apical decussate moderately strong pair of scutellar bristles, hardly one-half strength and length of the two lateral pairs, about same as the four discals which are set in a transverse row. Claws longer than last tarsal joint in male, especially front ones. Epistoma extremely developed, about as long as clypeus and of same size.

Uruhuasia (Subgenus B) has frontal bristles doubled anteriorly, but otherwise agrees in main with Uruhuasia (A) as opposed to Uruhuasiopsis.

Uruhuasiopsis analis, new species.

Length of body, $9 \mathrm{~mm}$., the abdomen being flexed; of wing, $8.5 \mathrm{~mm}$. One male, Huariaca, Peru, about 10,725 feet, December 20, 1913 (Townsend).

Head silvery pollinose with a faint golden reflection which is most pronounced on cheeks, the ground color of face and cheeks being light; parafrontals dark in ground color, with golden pollen; frontalia and first two antennal joints fulvous, third joint and arista blackish, palpi fulvous. Beard deep brassy, extending over cheeks and parafacials; the hairs of parafrontals black. Mesoscutum and scutellum covered with a thick coat of golden pollen of the same dull shade as that of front, no distinct vittæ; pleuræ a little less thickly pollinose in an oblique band extending from the shoulder to the middle coxæ. Abdomen deep purplish black, subshining, anal segment with coat of golden ashy pollen except narrow anterior margin. Venter concolorous with tergum. Legs blackish, tibiæ except bases rufous. Wings evenly smoky throughout, slightly yellow on base; both scales of tegulæ rich brownish yellow.

Holotype, No. 19421, U. S. Nat. Mus.

Pictoepalpus, new genus.

Genotype, Pictoepalpus clarus Townsend, new species. Differs from Chromoepalpus by the second aristal joint being 
very elongate; third antennal joint not rounded at tip, but truncate and subangular, much widened apically especially in male; wings shorter in proportion; apical cell not so elongate and not so widely open, ending farther before tip ; apical crossvein not bowed in conspicuously, a wrinkle at its origin which latter is not so close to hind margin; discal macrochætæ of second segment sparse, there being only a pair or two of discals the same as on third and anal segments. Anal segment with buttocks-bunches of macrochætæ in both sexes. Front tarsi of female much widened.

Pictoepalpus clarus, new species.

Length of body, 10 to $11 \mathrm{~mm}$. ; of wing, 9.5 to $10.5 \mathrm{~mm}$. Three males, one taken at Tamboraque, Peru, about 9,000 feet, April 3, 1910 ; the others taken at Matucana, Peru, about 8,000 feet, August 16, 1913, and May 1, 1914, the last being TD4256 (Townsend).

Ground-color clear light yellow. Head with silvery pollen, that of facial plate white, the rest of head with a golden tinge even including front. Frontalia and first two antennal joints rufous, third joint and arista black. Mesoscutum and scutellum wholly clear testaceous, silvery pollinose with a faint golden tinge, leaving more or less distinct remnants of seven narrow vittæ; pleuræ, coxæ, and femora practically the same testaceous shade as mesoscutum; tibix rather more fulvous, metatarsi rufous, rest of tarsi black. Abdomen broadly light yellow on sides of first three segments, leaving a clear testaceous subtriangular marking on second and third segments, that of third segment larger than that of second, a small fleck of the same color on lateral hind angle of second segment, a patch of same color in middle of first segment beneath scutellum, the anal segment entirely the same color extending on hind lateral angles of third; the testaceous portions of abdomen are clothed with the same pollen as that of mesoscutum. Venter wholly clear light yellow, except anal segment and narrow hind corners of second and third segments. In some specimens the testaceous of thorax and abdomen is considerably darker, especially on median triangles of abdomen 
and on buttocks spots of anal segment. Wings quite evenly smoky, a whitish oblique area extending from base of discal cell to end of first vein, sometimes invading the base of fourth posterior cell and most of second costal cell, often distinctly tinged with yellow; extreme base of wing yellowish, a blackish area immediately next to same. Tegulæ yellowish testaceous, matching the color of the thorax.

Holotype, No. 19422, U. S. Nat. Mus.

Two females, measuring 12 to $13 \mathrm{~mm}$., taken with the above male at Tamboraque, resemble same in the darker coloration of abdomen and thorax, and are probably the females of this species. The light patch of the wings is only faintly evident in the female.

\section{Vibrissoepalpus, new genus.}

Genotype, Vibrissoepalpus flavipes Townsend, new species.

Differs from Vibrissomyia as follows: Female only described. Vertex one and one-fourth times eye-width. Cheeks about three-fourths eye-height. Two proclinate fronto-orbitals. No ocellar bristles. Only one row of frontals. No isolated facio-orbitals, but parafacials with a row of rather closely set fine bristles of same strength as those of cheeks. Third antennal joint hardly longer than second, straight on front border, moderately widened, truncate at tip but truncation very slightly oblique. Proboscis below geniculation a little less than head-height. Two strong lateral scutellar bristles, a long hair-like nondecussate apical pair; rest of scutellum with spines, in about four irregular rows, the hindmost row submarginal. Abdomen much wider than thorax, rounded shortoval; second segment with median discal patch of spines not quite so wide as scutellar patch, the anterior middle ones shortest; third segment with a smaller median discal patch; second and third segments with marginal row interrupted opposite the discal patches, and with patch of lateral discals; anal segment covered with spines except from margin. Venter with bunches of spinelike macrochætæ. The macrochætæ of abdomen are truly spine-like but not heavily so. Heavy long spines on middle and hind femora and tibiæ. Claws hardly 
as long as last tarsal joint. Front tarsi of female widened. Vibrissoepalpus flavipes, new species.

Length of body, $13 \mathrm{~mm}$.; to end of spines, $15 \mathrm{~mm}$.; of wing, $12 \mathrm{~mm}$. One female, Pachacayo, Peru, about 12,000 feet, on flowers of Viguiera sp., March 2\%, 1913 (Townsend).

Whole face and cheeks deep buff-yellow, satiny, with gold pollen; parafrontals dark olive, produced by the thin gold pollen over black. Frontalia testaceous-brown; first two antennal joints nearly same shade of brown, third joint blackish. Occiput brassy pollinose, with brassy beard. Thorax about same as parafrontals, four dark olive vittæ faintly showing. Scutellum rufous, thinly silverly pollinose. Abdomen deeper rufous, with faint suggestion of silvery pollen on median line and along incisures. Legs bright fulvorufous, tarsi light lemon-yellow. Wings evenly light smoky, darker at base. Tegulæ deeply smoky.

Holotype, No. 19423, U. S. Nat. Mus. TD413\%.

Eumelanepalpus, new genus.

Genotype, Eumelanepalpus ruber Townsend, new species.

Differs from Melanepalpus as follows: Proboscis beyond geniculation as long as head-height. Second abdominal segment with discal bunch of macrochætæ covering median space from front margin back to marginal row. Hind marginal rows of second and third segments not broken. The last character also distinguishes the genus from Quadratosoma. The abdominal macrochætæ are quite as in Rhachoepalpus, but the genius differs from latter in absence of ocellar bristles, and in the elongate proboscis. The form of abdomen is quite as in Melanepalpus; and also nearly like that of Rhachoepalpus, but not so widened behind as in females of latter.

Eumelanepalpus ruber, new species.

Length of body, $13 \mathrm{~mm}$.; to end of spines, $14.5 \mathrm{~mm}$.; of wing, $13 \mathrm{~mm}$. One female, Uruhuasi Bridge, Peru, montanya of the Rio San Gaban Canyon, about 6,500 feet, February 3, 1910 , on flowers of Baccharis sp. (Townsend).

Head dull yellowish, parafrontals black, whole head thinly 
silvery pollinose. Frontalia brownish-rufous. Antennæ blackish. Thorax black, very thinly silvery, median pair of vittæ visible only in front. Scutellum wholly rufotestaceous. Abdomen deep rufous throughout above and below, segments 2 to 4 with median blackish triangle on base. Legs same rufous as abdomen, tarsi black. Wings deeply smoky throughout. Hind scale of tegulæ yellow-rufous, with short whitish fringe; front scale deep blackish-smoky, with long black fringe.

Holotype, No. 19424, U. S. Nat. Mus. TD3938.

\section{Euquadratosoma, new genus.}

Genotype, Euquadratosoma rubrum Townsend, new species.

Differs from Eumelanepalpus as follows: Female only described. No reclinate inner fronto-orbital immediately inside of the posterior proclinate one. Front at vertex occupying fully one-third head-width. Cheeks fully two-thirds eyeheight. Proboscis beyond geniculation about two-thirds headheight. Marginal row of macrochætæ of second segment arcuate in middle, being bulged forward from hind margin on median line. Marginal row of third segment broadly interrupted on median line. Buttocks bunches of spines not continuous, well separated, the anal segment more deeply emarginate. Joints of all the tarsi rather wide, those of front and middle legs quite noticeably so. Apical cell much more widely open, ending a little nearer to wing tip.

\section{Euquadratosoma rubrum, new species.}

Length of body, $13 \mathrm{~mm}$; to end of spines, $14.5 \mathrm{~mm}$.; of wing, $12.5 \mathrm{~mm}$. One female, Ollachea, Peru, high montanya of the Rio San Gaban Canyon, about 9,500 feet, February 2, 1910 , on flowers of an euphorbiaceous shrub (Townsend).

Differs in color from description of Eumelanepalpus ruber only as follows: Face and cheeks irregularly tinged with rufous or testaceous. Thoracic vittæ scarcely distinguishable. Scutellum narrowly edged with black on base. Abdomen with a broad blackish median vitta, broadest in front, gradually attenuate posteriorly. Femora black on basal half or 
more, coxæ largely black. Wings and tegulæ practically same.

Holotype, No. 19425, U. S. Nat. Mus.

Eusaundersiops, new genus.

Genotype, Eusaundersiops notata Townsend, new species.

Differs from Saundersiops as follows: Two short filiform palpal stubs, without bristlets. Proboscis one and one-half times head-height. Second aristal joint but little longer than wide. Abdominal macrochætæ practically spinelike, median discal patch on second segment but none on third, less than posterior half of anal segment spined. A few submarginal to discal lateral on second and third segments. Venter with spine bunches only on plates 1 and 2. Marginal rows of second and third segments continuous. A very weak hairlike proclinate pair of ocellar bristles. Parafacials and parafrontals thickly clothed with long hair.

Eusaundersiops notata, new species.

Length of body, $12 \mathrm{~mm}$.; to end of spines, $13.5 \mathrm{~mm}$.; uf wing, $12.5 \mathrm{~mm}$. Two males, east base of Huascaray Ridge, montanya of western edge of Jaen Province, Peru, about 7,000 feet, September 22, 1911, on foliage (Townsend).

Black. Face and cheeks silvery-gray, satiny. Parafrontals blackish, only faintly pollinose. Frontalia brown, showing pollen-bloom in oblique light. Antennæ wholly blackish, articulations faintly rufous. Palpi testaceous. Occiput ashy, beard quite gray. Thorax and scutellum shining greenish-black, very thinly dusted with pollen, latter showing mostly in front where the beginning of three narrow median vittæ is visible. Abdomen shining black, segments 1 to 4 broadly dark rufous on sides; segments 2 to 4 with pair of silvery pollinose spots on base, one on each side of median line, the pair on second segment small, those of anal segment extending over rufous lateral border on venter but appearing in certain lights to be interrupted by the rufous. Legs black, tibiæ tinged with rufous. Wings evenly smoky, darker at extreme base. Hind scale of tegulæ pure snow-white, with short white fringe; front scale deeply smoky, with long black fringe.

Holotype, No. 19426, U. S. Nat. Mus. 


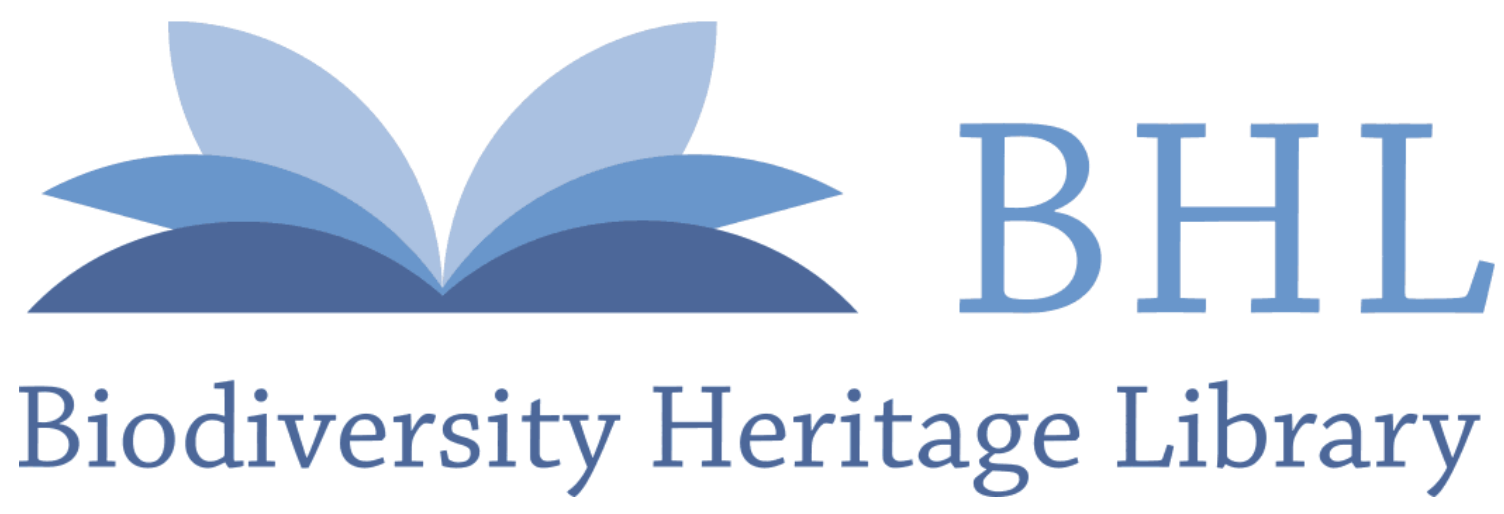

1915. "New peruvian hystriciine flies." Insecutor inscitiae menstruus 3, 69-76. https://doi.org/10.5962/bhl.part.8937.

View This Item Online: https://www.biodiversitylibrary.org/item/34104

DOI: https://doi.org/10.5962/bhl.part.8937

Permalink: $\underline{\text { https://www.biodiversitylibrary.org/partpdf/8937 }}$

\section{Holding Institution}

Smithsonian Libraries

\section{Sponsored by}

Smithsonian

\section{Copyright \& Reuse}

Copyright Status: NOT_IN_COPYRIGHT

This document was created from content at the Biodiversity Heritage Library, the world's largest open access digital library for biodiversity literature and archives. Visit BHL at https://www.biodiversitylibrary.org. 